\title{
Валентина Кравчук,
}

кандидат юридичних наук, дочент, доцент кафедри циивільного права і процесу Західноукраӥнського національного університету

ORCID: http://orcid.org/0000-0002-9211-7198

\section{ЛЮСТРАЦІЯ ЯК МЕХАНІЗМ ОЧИЩЕННЯ ВЛАДИ: ТЕОРЕТИЧНІ ТА ДЕОНТОЛОГІЧНІ ГРАНІ}

Розкрито теоретичні та деонтологічні аспекти люстрації. Люстрачія визначається як ефективний механізм очищення влади в перехідних демократіях, щуо направлений на усунення від влади посадовців, які себе скомпрометували або налаштовані антинародно. Деонтологічним аспектом люстрачії є ї̈ спрямованість на забезпечення доброчесності посадовців, яка передбачає і дотримання моральних принципів та етичних норм, $i$ законність джерел доходів та статків, і відсутність конфліктів інтересів, $i$ здатність посадової особи приймати справедливі й збалансовані за змістом рішення, незважаючи на будь-який зовнішній тиск. Механізм люстрації з теоретичного погляду охоплює сукупність взаємопов'язаних і взаємодетермінантних складників, до яких належать: правові норми, принципи, правові заходи, юридичні факти, правовідносини та ін. Люстрація має відбуватися відповідно до законодавства, щзо визначає ї̈ правові основи і принципи, які мають бути основою здійснення люстрачійних заходів і проиедур.

Ключові слова: люстрація, очищення влади, доброчесність, механізм люстрації, принципи люстрації.

\section{Кравчук В.}

\section{Люстрация как механизм очицения власти: теоретические и деонтологические грани}

В статье освещчены теоретические и деонтологические аспекты люстрации. Люстрация определяется как эффективный механизм очищения власти в переходных демократиях, направленный на устранение от власти чиновников, которые себя скомпрометировали или настроены антинародно. Деонтологическим аспектом люстрации является её направленность на обеспечение добропорядочности должностньх лиц, которая предусматривает и соблюдение моральных принцииов и этических норм, и законность источников доходов и состояния, и отсутствие конфликтов интересов, и способность должностного лица принимать справедливые и сбалансированные по содержанию решения, несмотря на любое внешнее давление. Механизм люстрации с теоретической точки зрения охватывает совокупность взаимосвязанных и взаимодетерминируюших компонентов, к которым относятся: правовые нормы, принципы, правовые меры, юридчческие факты, правоотношения и др. Люстрация должна совершаться в соответствии с законодательством, определяющим её правовые основы и принцииы, которые должны реально лежать в основе осуществления люстрационных мероприятий и проичедур.

Ключевые слова: люстрачия, очищеене власти, доброчестность, механизм люстрациии, принциипь люстрации.

\section{Kravchuk $\boldsymbol{V}$.}

Lustration as a mechanism of purification of state power: theoretical and deontological facets

The article is devoted to investigating of the theoretical and deontological aspects of lustration. Lustration is defined as an effective mechanism for purification of state power in transitional democracies, aimed at removing from power officials who have compromised themselves or are anti-people. The deontological aspect of lustration is its focus on ensuring the virtue (integrity) of officials, which provides for the observance of moral principles and ethical standards, and the legitimacy of sources of income and wealth, and the absence of conflicts of interest, and the ability of an official to make fair and balanced decisions, despite any external pressure. The lustrations mechanism, from a theoretical point of view, encompasses a set of interrelated and interdetermining components, which include: legal norms, principles, legal measures, legal facts, legal relations, etc.

Emphasis is placed on the technical and moral aspects of lustration. The first is that the authorities that carry out lustration must be legitimate. The second is the moral aspect. Often people who are not directly involved in the regime's crimes are subject to lustration. This means that people held certain positions that involved following the orders of the leadership, but in fact they did not do anything illegal. It is also important to ensure a balance between a

(c) Валентина Кравчук, 2021 
Кравчук В.

Люстрація як механізм очищення влади: теоретичні та деонтологічні грані

democratic society and human rights.

Lustration should be carried out in accordance with the legislation that defines its legal basis and principles, which should really underlie the implementation of lustration measures and procedures. For example, the principles of presumption of innocence, individual responsibility and guarantee of the right to defense, although enshrined in Ukraine in the text of the law, but in practice remained declarative, as was recognized by the ECtHR.

Keywords: lustration, purification of state power, virtue, the mechanism of lustration, the principles of lustration.

Постановка проблеми. В умовах кардинальних змін у напрямках політичного і соціального розвитку країни, в складні перехідні періоди в житті держави виникає попит на очищення владних ешелонів від корумпованих або антинародно налаштованих чиновників, на відновлення справедливості за минулі, скоєні ними, злочини. В такі періоди витребуваною є так звана «люстрація», хоч і вважається дещо суперечливим інструментом державного управління. Задіяння цього інструменту викликає великі труднощі управлінського характеру, однак за його ефективного застосування процес розбудови демократії та консолідації суспільства значно прискорюється.

В Україні після Революції Гідності, у 2014 р. було прийнято два закони, які у сукупності є законами про люстрацію: Закон України «Про очищення влади» [1] і Закон України «Про відновлення довіри до судової влади в Україні» [2], пізніше, у 2015 р., ухвалено ще Закон України «Про забезпечення права на справедливий суд» [3]. Незважаючи на те, що механізму люстрації надано законодавчої форми, не все так ідеально і бездоганно за реалізації цих процедур. Отож, проблематика очищення влади все ще актуальна, адже підвищення авторитету державних органів в Україні та відновлення довіри громадян до державної влади має відбуватися на науково обгрунтованих засадах і відповідно до європейських стандартів.

Аналіз останніх досліджень та публікацій. Питання люстрації, її ролі у механізмі захисту основ демократії та прав людини, ії значення як елемента публічного контролю, особливостях досвіду зарубіжних країн у їі проведенні неодноразово піднімалися у працях українських та зарубіжних учених. На особливу увагу заслуговують праці українських дослідників В. Ковальчука, В. Кравчука, В. Лемака, Н. Мінєнкової, О. Степаненка, В. Хлабистової, С. Шевчука та ін. Незважаючи на це, актуальним все ще є дослідження теоретичних та деонтологічних аспектів правової природи люстрації в умовах демократичних перетворень.

Метою публікації є визначення люстрації як механізму очищення влади, аналіз її теоретичних та деонтологічних аспектів.

Виклад основного матеріалу дослідження. Теоретико-правовий аналіз люстрації передбачає насамперед дослідження генези самого поняття. Термін «люстрація» (від лат. lustratio - очищення через жертвопринесення) має тривалу історію та в різні часи охоплював різні значення: ритуальні обряди очищення народу, флоту чи війська у Стародавньому Римі, державні господарсько-фінансові ревізії у Середньовіччі, політико-правові процедури (своєрідну перевірку та дискваліфікацію чиновників попереднього режиму) у XX ст. [4, с. 551]. Сьогодні люстрація - це явище, яке, як правило, відбувається в складні перехідні періоди у політичному житті держави. Зазвичай такі події пов'язані з кардинальними змінами у напрямку політичного і соціального розвитку країни, з трансформацією політичного і державного режиму 3 антидемократичного на демократичний.

У різних наукових джерелах люстрацію розглядають і як політико-правове явище, і як інститут права, і як спеціальну процедуру, і як елемент публічного контролю, що спрямований на забезпечення народовладдя, і як засіб кадрової політики держави та демократизації політичної системи, і як сучасну, особливу форму конституційно-правової відповідальності тощо. Загалом усі ці підходи не суперечать одне іншому, їхні автори лише акцентують увагу на найважливіших, на їхній погляд, аспектах цього явища.

За твердженням К. Хлабистової, яка присвятила вивченню цього явища свою дисертацію, люстрацію можна сприймати у широкому і вузькому значенні. «Широкий підхід забезпечує розгляд люстрації, як поліфонічного, перманентного, міжгалузевого публічно-правового явища, що являє собою реалізацію сукупності визначених чинним законодавством юридичних засобів (люстраційних заходів), спрямованих на запобігання та протидію деструкції публічної влади та забезпечення їі якісного функціонування. У вузькому розумінні люстрація - це інститут права, який має міжгалузевий характер і являє собою сукупність правових норм, що визначають різноманітні правові механізми, спрямовані на протидію та подолання деструкції публічної влади» [5, с. 85].

Н. Мінєнкова також виокремлює два підходи до розуміння люстрації: за першим, домінантним (традиційним), під люстрацією розуміють «усунення індивідів від політичного життя або юридичне покарання за дії під час попереднього режиму» [6, с. 154]. У такому визначенні зазначено, що люстрація 
передбачає систему каральних заходів щодо еліти й очільників минулих режимів та процедуру масових розслідувань щодо добровільних функціонерів минулого режиму. За альтернативним (ретроактивним) підходом акцентується увага не на покаранні, а на відновленні справедливості через розкриття відомостей про певні діяння особи, що вважалися злочинними. Покарання в цьому випадку має переважно додатковий сенс, адже підкріплює громадський осуд за вчинення таких діянь.

За твердженням Г. Малкіної, найбільш радикальні форми люстрації мають переваги, які полягають у тому, що: «по-перше, процес люстрації надає легітимності новій владі шляхом рішучого розриву 3 попереднім режимом, який сприймається суспільством як злочинний і неправовий; по-друге, люстрація є засобом запобігання реставрації попереднього недемократичного режиму та реваншизму старою елітою; по-третє, люстрація має показово-виховну роль, дає можливість суб'єктам політики та громадянському суспільству зрозуміти, що кожен громадянин має нести відповідальність за свої дії, наслідком чого є формування демократичної політичної культури» [7, с. 48].

Найпростіший підхід: люстрація - це процес, а точніше, механізм очищення влади. Таке визначення доволі лаконічне і водночас підкреслює основні аспекти: це явище має свою конструкцію, елементи якої взаємодіють та направлені на досягнення конкретної суспільної мети - усунення від влади посадовців, які скомпрометували себе, або антинародно налаштованих чиновників.

Деонтологічний акцент у визначенні люстрації ставить М. Савчин, який вказує, що це засіб забезпечення лояльності посадовців, чиновників і суддів до конституційної демократії, їхньої моральної цілісності і відкритості до громадянського суспільства. «3 точки зору верховенства права та прав людини, люстрація не може замінювати будь-який вид юридичної відповідальності. Вона може застосовуватися задля забезпечення поступального розвитку конституційної демократії та забезпечення моральної цілісності посадовців і суддів» [8, с. 10].

Так, люстрація має на меті очищення корпусу посадовців від недоброчесних чиновників, і йдеться тут не лише про перевірку статків і доходів. Доброчесністю, за визначенням С. Глущенко, є «моральноетичний фундамент діяльності, який визначає межу і спосіб поведінки, яка має грунтуватися на принципах добровідносин із громадянами, суспільством та державою, а також чесності у способі життя, виконанні професійних обов'язків та розпорядженні матеріальними ресурсами» [9, с. 78]. Отож, доброчесність передбачає і дотримання моральних принципів та етичних норм, і здатність посадової особи ухвалювати збалансовані й справедливі за змістом рішення, незважаючи на будь-який зовнішній тиск. М. Савчин зазначає, що доброчесність - це моральна цілісність особи, яка полягає у «здатності розважливо і розсудливо з'ясовувати всі істотні обставини справи, належним чином поєднувати фактичний і юридичний склад, давати належну аргументацію рішень, які мають бути засновані на повазі до гідності та прав людини» [8, c. 14]. Під час проходження служби посадовцем чи здійснення правосуддя суддею та й поза межами своєї професійної діяльності вони мають демонструвати бездоганну поведінку, яка засвідчувала б відсутність конфлікту інтересів.

3 точки зору теорії, механізм люстрації - це іiї внутрішня системна будова, що забезпечує їі втілення у правову реальність, тобто безпосереднє їі застосування. Серед елементів такого механізму К. Хлабистова виокремлює: правові норми, принципи, правові заходи, юридичні факти, правовідносини та ін. [5, с. 67-68]. Хоча це не повний перелік складників механізму люстрації, але достатній для характеристики в межах цієї публікації.

Однією із ключових вимог до люстрації є їі законодавче визначення, нормативне закріплення люстраційних процедур. За відсутності законодавчого врегулювання (у Чехословаччині 1989-1991 рр., Польщі 1989-1998 рр.) люстрація асоціювалася з незаконними діями на кшталт шантажу, таємної підривної чи кримінальної діяльності, а також взаємних звинувачень, політичних скандалів та зловживань владою [10, c. 130]. Закони про люстрацію не є панацеєю для нейтралізації мереж старої влади, однак вони можуть зробити значний внесок у підсилення демократії, що формується, особливо після того, як виявилося, що суто структурні зміни неефективні.

У процесі здійснення люстрації важливо дотримуватися певних принципів, які теж мають бути закріплені законодавчо. Так, у ч. 2 ст. 1 Закону України «Про очищення влади» встановлено, що люстрація в Україні грунтується на принципах «верховенства права та законності; відкритості, прозорості та публічності; презумпції невинуватості; індивідуальної відповідальності; гарантування права на захист» [1]. Крім цих засад, важливе значення також мають: принцип комплексності та послідовності заходів, принцип доцільності, принцип доброчесності, принцип юридичної визначеності [5, с. 86]. 
Кравчук В.

Люстрація як механізм очищення влади: теоретичні та деонтологічні грані

Люстраційні заходи, як визначають науковці, можна розглядати як «визначені законом форми впливу або на особу, яка відповідає критеріям об'єкта очищення влади, або на певний об'єкт у сфері відповідних відносин, що здійснюються через відповідну юридичну діяльність уповноважених суб'єктів» [5, c. 240]. У різних державах люстрація може передбачати різні як обмежувальні, так і профілактичні правові заходи щодо колишніх державних службовців, що цілком і повністю залежать від історичних подій, результатом яких є необхідність їх застосування. Зокрема, люстраційними заходами є такі: зняття недоторканності; відкриття кримінальних справ; перевірки на поліграфі; заборони на ведення певного виду політичної діяльності; заборони займати певні посади; позбавлення привілеїв і преференцій тощо.

Щодо суддів, Закон України «Про відновлення довіри до судової влади в Україні» передбачив правові та організаційні засади проведення спеціальної перевірки суддів як тимчасового посиленого заходу з використанням наявних процедур розгляду питань про притягнення суддів до дисциплінарної відповідальності і звільнення з посади у зв'язку з порушенням присяги. Закон України «Про забезпечення права на справедливий суд» закріпив зміни до законодавчих актів України з метою підвищення національних стандартів судоустрою і судочинства. Фактично за цими Законами відбувся специфічний перезапуск судової системи, чергова судова реформа, у результаті якої змінився судоустрій та статус суддів, а головною їі метою стало очищення судової влади від суддів, які непропорційно застосовували заходи відповідальності до учасників Революції Гідності.

Важливо акцентувати увагу на технічному й моральному аспектах у процесі проведення люстрації. Перший полягає в тому, що влада, яка здійснює люстрацію, має бути легітимною. Це означає, що органи державної влади мають бути абсолютно законно обраними і їх має підтримувати більшість народу. За відсутності цього факту люстрація вважається розправою над політичними суперниками.

Другий - це моральний аспект. Справа в тому, що нерідко під люстрацію потрапляють особи, які безпосередньо не причетні до злочинів режиму. Це означає, що особи займали певні посади, які припускали виконання наказів керівництва, але фактично нічого незаконного і протиправного вони не здійснювали. Щодо таких людей потрібно брати до уваги всі аспекти справи, щоб очищення не перетворилося на розправу.

Також важливо забезпечити баланс між демократичним суспільством та правами людини. Так, на думку фахівців з питань люстраційного законодавства, певні положення українського закону суперечать правам людини і громадянина та ставлять під сумнів ті демократичні цінності, які люстрація має захищати. Венеціанська комісія звернула увагу на деякі недоліки Закону України «Про очищення влади», зокрема щодо кола осіб, до яких він застосовується (було визначено надмірно широкий перелік посадових осіб, яким було обмежено доступ до посад на публічній службі; більшість цих посад не передбачала прийняття рішень політичного значення чи пов'язаних із суттєвим обмеженнями прав людини, а отже, необхідно обмежувати люстрацію найважливішими посадами у державі), часової складової (два періоди заборони тощо), управління процесом люстрації (децентралізована процедура, не було створено незалежного люстраційного комітету, який би розглядав за встановленою процедурою справи на кожну особу, що обіймала посаду, на які поширювалися обмежувальні заходи щодо доступу до публічної служби) і процесуальних гарантій (персональна відповідальність, захист персональних даних осіб, які підлягають люстрації, можливість оскарження у судовому порядку тощо).

Європейський суд з прав людини констатував, що український Закон «Про очищення влади» не повністю відповідає європейським стандартам і принципу верховенства права (рішення ЄСПЛ у справі «Полях та інші проти України» від 17 жовтня 2019 року) [11]. ССПЛ не визнав неправомірною люстрацію загалом, а лише іiі надмірний обсяг. Так, зокрема, зазначив, що застосування до заявників передбачених Законом «Про очищення влади» заходів не передбачало жодної індивідуальної оцінки їхньої поведінки. «Насправді, ніколи не стверджувалося, що самі заявники вчинили які-небудь конкретні дії, що підривали демократичну форму правління, верховенство права, національну безпеку, оборону або права людини. Вони були звільнені на підставі Закону лише тому, що обіймали певні відносно високі посади державної служби, коли Янукович був Президентом України» [11]. ССПЛ також визнав, що Україна порушила право на справедливий суд у зв'язку із занадто тривалим розглядом справ колишніх чиновників, а також право на повагу до приватного та сімейного життя. 24 лютого 2020 р. Велика палата ЄСПЛ розглядала апеляцію на це рішення, однак підтвердила його, а в апеляції Україні відмовила. Це рішення Великої палати ЄСПЛ $є$ остаточним і оскарженню не підлягає.

3 огляду на висновки, яких дійшов ЄСПЛ у цій справі, вважаємо доволі обгрунтованою думку В. Кравчука про те, що «люстрація як форма юридичної відповідальності є безперспективною з точки зору 
демократичних та правових засобів очищення публічної влади від лояльних до корупції публічних службовців. Однак якщо люстрація як складова публічного контролю застосовується як моральне засудження та спосіб розкриття відомостей про осіб - претендентів на публічні адміністративні посади, вона є результативною» $[12$, с. 70]. Таким чином, дослідник пропонує застосовувати люстрацію як правовий механізм декларування біографічних відомостей, що сприятиме публічному моніторингу та контролю. Люстрація як інформаційний інструмент є більш ефективною, оскільки відображати необхідну інформацію будуть зобов>язані особи, які претендують на відповідальні управлінські посади, а оцінюватиме цю інформацію надаватиме безпосередньо громадськість.

Висновки. Таким чином, люстрація є ефективним механізмом очищення влади в перехідних демократіях, що направлений на усунення від влади посадовців, які себе скомпрометували або налаштовані антинародно. Особливо важливим деонтологічним аспектом люстрації є ії спрямованість на забезпечення доброчесності посадовців, яка передбачає і дотримання моральних принципів та етичних норм, i законність джерел доходів та статків, і відсутність конфліктів інтересів, і здатність посадової особи приймати справедливі й збалансовані за змістом рішення, незважаючи на будь-який зовнішній тиск.

Механізм люстрації охоплює сукупність взаємопов'язаних і взаємодетермінантних складників, до яких належать: правові норми, принципи, правові заходи, юридичні факти, правовідносини та ін. Важливо дотримуватися технічного і морального аспектів у процесі проведення люстрації, забезпечення балансу між демократичним суспільством та правами людини. Люстрація має відбуватися відповідно до законодавства, що визначає їі правові основи і принципи. Більш того, принципи повинні реально бути основою здійснення люстраційних заходів і процедур. Як бачимо на власному прикладі, принципи презумпції невинуватості, індивідуальної відповідальності та гарантування права на захист, хоч і були в Україні закріплені в тексті закону, але на практиці залишилися декларативними, що визнав ССПЛ.

Загалом в Україні люстрація потроху згортатиметься «природним шляхом», адже фактично всіх, на кого поширювалась дія Закону «Про очищення влади», люстрували ще у 2015 р. Однак Україна, забезпечивши реалізацію індивідуального підходу до люстраційних процедур із розглядом справ кожного конкретного «претендента» і його права на оскарження, не змушена була би тепер виконувати рішення ЄСПЛ, виплачуючи солідні компенсації, доволі суттєві для державного бюджету.

\section{Список використаних джерел}

1. Про очищення влади : Закон України № 1682-VII від 16 вересня 2014 року. Редакція від 20.03.2020. URL: https://zakon.rada.gov.ua/laws/show/1682-18\#Tеxt (дата звернення: 10.08.2021).

2. Про відновлення довіри до судової влади в Україні : Закон України № 1188-VII від 8 квітня 2014 року. Редакція від 05.01.2017. URL: https://zakon.rada.gov.ua/laws/show/1188-18\#Tехt (дата звернення: 03.08.2021).

3. Про забезпечення права на справедливий суд : Закон України № 192-VIII від 12 лютого 2015 року. Редакція від 05.01.2017. URL: https://zakon.rada.gov.ua/laws/show/192-19\#Text (дата звернення: 06.08.2021).

4. Ковальчук В., Пивовар М. Люстрація як механізм захисту основ демократії та прав людини в Україні. Вісник Національного університету «Львівська політехніка». Сер. : Юридичні науки : зб. наук. праць. Львів : Вид-во Львівської політехніки, 2017. № 865. С. 550-556.

5. Хлабистова К. В. Інститут люстрації: конституційно-правові засади регулювання та вдосконалення : дис. ... к.ю.н. за спеціальністю 12.00.02. Київ, 2017. 250 с.

6. Мінєнкова Н. Люстрація в Польщі та Чехії: розбіжність типів, чинників та наслідків. Studia Politologica Ucraino-Polona. 2014. T. 4. C. 153-157.

7. Малкіна Г. М. Люстрація як форма політичної відповідальності : матеріали доп. та виступів на Міжнар. наук. конф. «Дні науки філософського факультету - 2015» (21-22 квіт. 2015 р.) / редкол.: А. С. Конверський та ін. Київ : Видав.-поліграф. центр «Київський університет», 2015. Ч. 10. С. 46-49.

8. Савчин M. Moral integrity (моральна цілісність, доброчесність) суддів як складова правової держави. Слово Національної иколи суддів Украӥни. 2019. № 2 (27). С. 6-22.

9. Глущенко С. В. Новели судової реформи: поняття професійної етики та доброчесності в контексті кваліфікаційного оцінювання судді (кандидата на посаду судді). Часопис изивільного $і$ кримінального судочинства. 2016. № 6. С. 70-83.

10. Клімова С., Ковальова Т. Організаційно-правове забезпечення сучасної антикорупційної політики: навчальний посібник. Харків, 2015. 252 с. 
11. Рішення ССПЛ у справі «Полях та інші проти України» (Заява № 58812/15 та 4 інші заяви) від 17 жовтня 2019 року. URL: https://zakon.rada.gov.ua/laws/show/974_e71\#Text.

12. Кравчук В. Інститут люстрації як елемент публічного контролю: юридичний аналіз. Науковий часопис Національної академії прокуратури України. 2016. № 1. С. 65-72.

\section{References}

1. Pro ochyshchennia vlady: Zakon Ukrainy № 1682-VII vid 16 veresnia 2014 roku. Redaktsiia vid 20.03.2020 [On the purification of power: Law of Ukraine № 1682-VII of September 16, 2014. Edited from 20.03.2020]. Retrieved from https://zakon.rada.gov.ua/laws/show/1682-18\#Text [in Ukrainian].

2. Pro vidnovlennia doviry do sudovoi vlady v Ukraini: Zakon Ukrainy № 1188-VII vid 8 kvitnia 2014 roku. Redaktsiia vid 05.01.2017 [On Restoration of Confidence in the Judiciary in Ukraine: Law of Ukraine № 1188VII of April 8, 2014. Edited from 05.01.2017]. Retrieved from https://zakon.rada.gov.ua/laws/show/118818\#Text [in Ukrainian].

3. Prozabezpechennia prava na spravedlyvyi sud: Zakon Ukrainy № 192-VIII vid 12 liutoho 2015 roku. Redaktsiia vid 05.01.2017 [On ensuring the right to a fair trial: Law of Ukraine № 192-VIII of 12 February 2015. Edited from 05.01.2017]. Retrieved from https://zakon.rada.gov.ua/laws/show/192-19\#Text [in Ukrainian].

4. Kovalchuk, V. \& Pyvovar, M. (2017). Liustratsiia yak mekhanizm zakhystu osnov demokratii ta prav liudyny $\mathrm{v}$ Ukraini [Lustration as a mechanism to establish the foundations of democracy and human rights in Ukraine.]. Visnyk Natsionalnoho universytetu «Lvivska politekhnika» - Bulletin of the National University "Lvivska Politechnika», 865, 550-556 [in Ukrainian].

5. Khlabystova, K.V. (2017). Instytut liustratsii: konstytutsiino-pravovi zasady rehuliuvannia ta vdoskonalennia [Institute of lustration: constitutional and legal principles of regulation and improvement]. Candidate's thesis. Kyiv [in Ukrainian].

6. Minienkova, N. (2014). Liustratsiia v Polshchi ta Chekhii: rozbizhnist typiv, chynnykiv ta naslidkiv [Lustration in Poland and the Czech Republic: the difference of types, factors and consequences]. Studia Politologica Ucraino-Polona, 4, 153-157 [in Ukrainian].

7. Malkina, H.M. (2015). Liustratsiia yak forma politychnoi vidpovidalnosti [Lustration as a form of political responsibility]. Proceedings from Mizhnarodna naukova konferentsia «Dni nauky filosofskoho fakultetu 2015» International Scientific Conference «Days of Science of the Faculty of Philosophy - 2015», 46-49) [in Ukrainian].

8. Savchyn, M. (2019). Moral integrity (moralna tsilisnist, dobrochesnist) suddiv yak skladova pravovoi derzhavy [Moral integrity of judges as a component of the rule of law]. Slovo Natsionalnoi shkoly suddiv Ukrainy - Word of the National School of Judges of Ukraine, 2 (27), 6-22 [in Ukrainian].

9. Hlushchenko, S. V. (2016). Novely sudovoi reformy: poniattia profesiinoi etyky ta dobrochesnosti v konteksti kvalifikatsiinoho otsiniuvannia suddi (kandydata na posadu suddi) [Novels of judicial reform: the concept of professional ethics and integrity in the context of qualification assessment of a judge (candidate for judge)]. Chasopys tsyvilnoho i kryminalnoho sudochynstva - Journal of Civil and Criminal Procedure, 6, 70-83 [in Ukrainian].

10. Klimova, S. \& Kovalova, T. (2015). Orhanizatsiino-pravove zabezpechennia suchasnoi antykoruptsiinoi polityky [Organizational and legal support of modern anti-corruption policy]. Kharkiv [in Ukrainian].

11. Rishennia YeSPL u spravi «Poliakh ta inshi proty Ukrainy» (Zaiava № 58812/15 ta 4 inshi zaiavy) vid 17 zhovtnia 2019 roku. [Judgment of the European Court of Human Rights in the case "Polyah and Others $v$. Ukraine» (Application № 58812/15 and 4 other applications) of 17 October 2019]. Retrieved from https:// zakon.rada.gov.ua/laws/show/974_e71\#Text [in Ukrainian].

12. Kravchuk, V. (2016). Instytut liustratsii yak element publichnoho kontroliu: yurydychnyi analiz [The institute of lustration as an element of public control: legal analysis]. Naukovyi chasopys Natsionalnoi akademii prokuratury Ukrainy - Scientific journal of the National Academy of the Prosecutor's Office of Ukraine, 1, 65-72 [in Ukrainian]. 